rather well, with 11 of these. The MRC works on the human scale, however; the SRC, which is responsible for 'big science', believes it has to have its expensive equipment housed in central facilities, shared by the country as a whole. This argument is rather damaged by the fact that its major 'centre', consisting of the Rutherford Laboratory (particle physics), the Culham Laboratory (plasma physics), the National Computer Laboratory, the High Power Laser Facility and the Appleton Laboratory (space and atmospheric research), is very conveniently situated for London, but is well south of the academic centre of the UK, which is strongly weighted by the Northern and Scottish universities.

This is a mere peccadillo compared to the policy of the biggest research spender of the country, the Ministry of Defence. Of the 45 major research establishments listed by the MOD, apart from the lonely Naval Construction Research Establishment in Dunfermline, none are farther north than Baldock, 35 miles from London. As part of the devolution package the government has promised to move the MOD to Glasgow, which has a chronic unemployment problem. Every few weeks Glaswegians read in their newspapers, with a mixture of anger and amusement, the ideas of civil servants on the putative great trek North. The most common view seems to be that civilisation stops at Chingford and the Arctic Circle begins at Watford Gap.
Hopefully, if the MOD is ever moved it will learn the error of its views and devolve some of its research establishments also.

\section{Eternal drawback}

What, then, about industrial research? While the government tries to encourage industry to the North with various short term benefits, there is an eternal drawback in that Scotland is at the periphery of Europe, and transport costs must always be high. This adds about $£ 50$ to the cost of a car made in Scotland rather than Birmingham. The more valuable the basic product, however, the less significant are these transport costs, and thus factories producing high technology items are least affected. This has been recognised by the American computer giants, and Honeywell, IBM, NCR, and Hewlett Packard all have factories in Scotland. They are just factories, however, and the best Scottish managerial and research personnel are siphoned off to England or abroad. Could the process be reversed by independence? This seems doubtful, in that a small Scotland is unlikely to be more successful at dealing with a high-technology multinational than the $\mathrm{UK}$ as a whole.

The lack of investment in new technology is also borne out by the experiences of the National Engineering Laboratory (NEL) at East Kilbride. Seven years ago the Rothschild committee recommended that the NEL should become less academic and liaise more with industry - should become, in effect, East Kilbride's answer to MIT. To a certain extent this has worked: of an annual budget of $£ 10,000,000$, industry now contributes $£ 1,250,000$, and of NEL's marketable ideas about half are taken up by local Scottish industry-eventually. John McAllen of NEL's industrial marketing unit is, however, depressed at the lack of interest that most of industry displays in trying to identify areas where new technology could be developed. Especially depressing is the tale of NEL's hydraulically driven dumper truck. In spite of a total lack of industrial interest NEL were convinced that this idea had promise, and developed it on their own. Their perseverance paid off, and eventually Carron Hydraulics of Falkirk took out a franchise on the invention. When the potential of the idea was proved, however, Carron Hydraulics was promptly taken over by the German Rexroth group.

The story of other countries reaping the rewards from Biritish inventions is now only too familiar. The worrying aspect of this case is that the invention was developed with government money specifically to benefit British industry; safeguards against subsequent foreign takeover should have been written in. The NEL is, nevertheless, of great importance to Scotland, both as an employer of scientific personnel and as a stimulus to industry. Its status in an independent Scotland would be very doubtful.

\title{
Maintaining momentum
}

Colin Norman reports from

Washington on latest developments concerning recombinant DNA research

THE debate over the risks and benefits associated with recombinant DNA research, which has been raging in college campuses and city halls around the United States, suddenly picked up momentum in Washington last week. At one end of town, a public meeting sponsored by the National Academy of Sciences provided a forum for a clash of views on whether, and under what circumstances, such research should be permitted. At the other end of town, Representative Paul Rogers, chairman of the House health subcommittee, proposed legislation to regulate all recombinant DNA research in the United States. And in suburban Bethesda, a committee of officials from several government agencies met to try to draft a bill to be sponsored by the Carter Administration.
About the only clear message to emerge from this flurry of activity is that legislation to control recombinant DNA experiments throughout the United States is now inevitable, and that it would be welcomed even by many of the scientists who have long shivered at the thought of having an agency of the federal government regulate their research. But there was the glimmering of another message, at least in the Academy's public meeting. There emerged at the meeting vocal opposition to recombinant DNA research from non-scientists concerned about its potential long-term implications for human genetic engineering. Most of the debate so far has swirled around immediate health hazards, but it may slowly be shifted toward a discussion of the potential uses to which the research may ultimately be put.

First, the legislative developments. The National Institutes of Health (NIH) guidelines published last June formally apply only to recombinant DNA research supported by the federal government, and are not backed by any federal monitoring or enforcement mechanism. Industrial research is not formally regulated at present. Because of these apparent weaknesses some state and local governments are considering adopting their own enforceable regulations. Faced with that prospect, many scientists who once resisted federal legislation would now welcome it.

Whether scientists want it or not, however, legislation is definitely coming. For the past four months a task force of some 25 officials from federal agencies has been seeking ways to extend the NIH guidelines to cover all recombinant DNA research in the United States and to monitor compliance with the guidelines. The task force has recently concluded that no existing federal agency has the authority ito carry out those roles, and that new legislation is therefore needed.

The task force met last week to try to draft a bill for approval by the Secretary of Health, Education and 
Welfare (HEW), who would then submit it to Congress. The task force didn't complete its work, however, and it will meet again this week. Its draft legislation is expected to recommend the establishment of a licencing scheme, administered by an agency of $\mathrm{HEW}$ (possibly the Center for Disease Control), for research involving recombinant DNA. In any case, the controls to be enforced on the research will be the NiH guidelines.

Meanwhile, Representative Paul Rogers has already got off the mark with a bill of his own. On 8 March, he made a speech in the House outlining

In an action which has so far attracted little public attention, a biologist at the University of California has been forced to destroy a large and painstakingly constructed clone bank because the clones were produced under conditions disallowed by the NIH guidelines governing recombinant DNA experiments. The incident has been described by some scientists as a good example of the way that the voluntary NIH guidelines can work to protect public health, but others have suggested that it underlines the need for more careful scrutiny of recombinant DNA research proposals before experiments are begun.

The research, carried out by John Carbon of the University of California at Santa Barbara, was performed between mid-1974 and mid-1976, a time when the NIH guidelines were under development. During most of that period, recombinant DNA research in the United States was governed by a loose set of safety guidelines drafted by a group of scientists which met early in 1975 at Asilomar, California. Those Asilomar guidelines did not rule out Carbon's experiments and even the final NIH guidelines, published on 23 June 1976 , are a little ambiguous on the matter. Carbon thus did not infringe guidelines in force while he was conducting the experiments and he says he was unaware that his work lay outside the final NIH guidelines.

The work consisted essentially of constructing a large bank of clones of $E$. coli containing transplanted yeast genes and fruit fly genes. Taking the clone bank of yeast genes as an example, this, in short, is what Carbon did:

He extracted the entire nuclear DNA from yeast cells and chopped it up into small fragments by mechanical shearing. He then spliced the yeast DNA fragments into bacterial plasmids and inserted the hybrid plasmids into $E$. coli. The next step was to culture the bacteria, growing several thousand distinct colonies, and each colony was then harvested separately. The collection of colonies constitutes a clone bank containing copies of DNA fragments, representing the entire yeast genome, spliced into plasmids inside living bacteria.

None of that would ordinarily be considered hazardous; indeed, the NIH guidelines specify that such manipulations with yeast genes require only low (P2) levels of physical containment. The problem, however, was that the $E$. coli which Carbon used to clone the hybrid plasmids also contained so-called fertility, or F, plasmids which promote the transfer of genetic information from one bacterial strain to another. This means some of the risks and benefits potentially arising from recombinant DNA research, and announced that he would introduce legislation to control the research and that his health subcommittee would hold public hearings on the measure on 15, 16 and 17 March. The following day, he introduced a bill co-sponsored by nine other members of his subcommittee.

The timing of the move was based on political considerations. The House Committee on Science, Research and Technology announced last week that it would hold a series of public hearings on recombinant DNA research during

that the hybrid plasmids contained in the $E$. coli might easily be transferred into other $E$. coli strains capable of surviving in the natural environment. In other words, use of bacteria containing $F$ plasmids greatly lowers the barriers preventing escape of recombinant DNA molecules from the laboratory.

The scientific advantage of the system, however, is that it can be used for rapid identification of the transplanted genes, and it can also be used simply to test whether they are capable of being expressed in their new host. Essentially, Carbon transferred the plasmids from the $E$. coli bank into other strains and tested to see whether the properties of the new host were altered. In a paper published in the February issue of the Proceedings of the National Academy of Sciences, for example, Carbon and his co-workers report evidence that yeast genes are being expressed in their new hosts.

Last June, a couple of weeks before the NIH guidelines were published, Carbon presented the results of his work at a symposium on recombinant DNA held at Massachusetts Institutes of Technology, and his use of a system containing $F$ plasmids was challenged on grounds of safety. Then, shortly after the NIH guidelines were issued, Carbon wrote to the NIH Recombinant DNA Advisory Committee for a ruling on whether or not his system is proscribed by the guidelines. The committee informed him last October that the guidelines should be interpreted as ruling out the use of $E$. coli containing F plasmids, and it instructed him to destroy his clone banks. Carbon was, however, given time to extract those plasmids which he wished to keep and transfer them to safer strains. He complied with the ruling last November.

Asked last week when he first had doubts about whether his experiments infringed the guidelines, Carbon said that "the realisation dawned on us slowly over the course of several weeks last spring". He said, however, that the guidelines do not specifically rule out use of his system, and he was therefore still uncertain about the propriety of his experiments even when the guidelines were issued. Other scientists queried last week said that although the guidelines are a little fuzzy on the matter, they thought that it was generally assumed that $E$. coli with $F$ plasmids shouldn't be used. In any case, Carbon said that he is "willing to go along with the guidelines" and he destroyed more than 50,000 clones containing yeast genes and some 10,000 clones containing Drosophila genes. the last week of March, and Senator Kennedy's Senate health subcommittee is planning to hold hearings early in April, after the Administration's bill is introduced into Congress. Rogers didn't want to be in the position of seeming to react to events, so he had his staff draft a bill last week in record time.

When he introduced the bill, Rogers noted that "this proposal is intended to be a vehicle for discussion ... . and does not necessarily represent the views of its co-sponsors." Its chief provisions are as follows :

- It would require the Secretary of HEW to issue regulations governing recombinant DNA research which would be "no less stringent than the physical and biological containment requirements prescribed by the $(\mathrm{NIH}$ guidelines)". The regulations would also specify a role for institutional review committees.

- Any researcher wishing to conduct recombinant DNA experiments would have to obtain a licence from HEW, the application for which would describe the experiment and the conditions under which it would be performed. Licences would be valid for a maximum of two years.

- The bill would limit the number of high-containment (P4) facilities in the United States to ten centres.

- It would require the Secretary of HEW to publish in the Federal Register a description of projects for which licences have been granted, though trade secrets would be exempted from public disclosure.

- The Secretary would be empowered to inspect facilities in which recombinant DNA research is conducted, to ensure compliance with the regulations. - Violations of the regulations would result in civil fines of $\$ 1,000$ per day. - The bill specifies that federal regulations would pre-empt local controls on recombinant DNA nesearch, except that the Secretary could exempt local controls which are at least as strict as the federal regulations.

- Finally, it would establish an advisory committee to assist the Secretary in the granting of licences for recombinant DNA research.

Last month a bill establishing a licencing scheme and providing harsh penalties for violations of the regulations was introduced by Senator Dale Bumpers and Representative Richard Ottinger. Senator Kennedy may also draft a bill of his own. The final version to emerge will be a compromise between many different proposals, though particular attention should be paid to the Rogers bill if only because he is in a key position to steer his proposals through the House. A recent notable addition to Rogers' subcommittee staff is Burke Zimmer- 
man, a former representative of the Environmental Defense Fund who has long been active in seeking more public debate and stricter controls on recombinant DNA research.

While those legislative developments were taking place last week, the Academy's public meeting was in full, and sometimes noisy, swing at the other end of the Mall. Though the meeting essentially covered ground which has already been well trodden in college campuses and city halls around the country, it nevertheless generated considerable national attention and not a little friction.

Most of the high-temperature exchanges took place at the opening session, when a group called the Peoples' Business Commission (a reincarnation of the Peoples' Bicentennial Commission) staged a series of disruptions. Jeremy Rifkin, a spokesman for the group, was invited to address the meeting to air his grievances, and as he did so several of his supporters unfurled banners proclaiming their opposition to the research. Rifkin harangued the organisers of the meeting, claiming that the fact that it was supported financially by several drug companies rendered it suspect. In particular, Rifkin claimed that because the agenda was dominated by sessions concerned with potential health hazards from recombinant DNA research, it missed the central question of how the long-term implications of the research should be dealt with. Genetic engineering, he opined, is "the most important issue that society has to grapple with", and he told the researchers present that "you can't hide from the facts any more than the physicists who split the atom".

Although the interruptions and objections formed just a part of the meeting, Rifkin's objections did surface later in rather more subtle form, from speakers such as Jon Beckwith of Harvard, who noted that though there are still some barriers left to introducing genes into human cells, "these goals are not at all inconceivable and they may be achieved very rapidly". Beckwith announced that he has renounced use of recombinant DNA techniques, because "I do not wish to contribute to the development of a technology which I believe will have profound and harmful effects on this society".

Other speakers noted that one of the potential benefits often claimed for recombinant DNA is to help understand the causes of cancer. Such observations put the debate onto a different level from discussion of potential health hazards, and they could be much more difficult for scientists to grapple with.

\section{Sweet sorrow}

AFTER more than six years of uncertainty, the Food and Drug Administration (FDA) last week decided to ban the artificial sweetener saccharin from general use in the United States. The action, which was prompted by clear evidence that the sweetener can cause bladder cancer in rats when fed to them in large quantities, immediately prompted shrill protests from the food industry, and it is sure to touch off a new round of attacks on the so-called Delaney Amendment which bans use of any food additive found to cause cancer in animals.

The evidence which finally sounded the death knell for saccharin came from a long-term feeding study sponsored by the Canadian government, preliminary results of which were made available to FDA officials on 7 March. Two days later, FDA and the Canadian Department of Health and Welfare announced that the sweetener would be banned both in Canada and the United States.

The full results of the study have not been published, but according to a summary made available by FDA, it turned up the following results. Out of 50 male and 50 female rats fed a diet containing $5 \%$ saccharin throughout their lives, three males and no females developed malignant bladder tumours. In addition, 50 male and 50 female offspring of those rats were also fed diets loaded with saccharin. The cancer incidence among them was more pronounced: 12 male and 2 female animals developed bladder tumours. Thus, 17 out of 200 test rats developed cancer compared with 2 out of 100 in a control group.

Until the full results are published, it is difficult to tell how good the study was. It has, however, long been regarded as the best test of saccharin yet undertaken, and FDA officials have been eagerly awaiting the results in the expectation that the study would finally settle the question of whether saccharin is or is not a carcinogen. They were impressed. The tests, according to Sherwin Gardner, the Acting FDA Commissioner, "show unequivocally that this substance can produce malignant bladder tumours in rats".

It has sometimes been suggested that the carcinogenic potential of saccharin may be caused not by the sweetener but by an impurity, orthotoluenesulphonamide (OTS). The Canadian tests, however, included a separate study of OTS and no carcinogenic effects were discovered.
FDA was therefore left with no choice but to ban saccharin from the market, an action which Gardner suggested was "based on science and on the requirements of Federal law". FDA hopes to publish details of the ban within a month, but it will allow those products already manufactured to be sold.

The ban could have considerable economic impact since saccharin is now the only artificial sweetener on the market in the United States. Cyclamates were banned in 1969, following evidence that they also cause bladder cancer in rats. And another sweetener, aspartame, was due to be approved by FDA a couple of years ago but approval was withdrawn following a discovery that the manufacturer of the substance submitted misleading test data. Once saccharin is removed from the market, there will be no non-nutritive sweetener for use by the burgeoning diet food industry. Some 5 million pounds of saccharin is now used in the United States, about three quarters of which goes into soda pop.

FDA's regulation of saccharin came under blistering attack last year in a study published by the General Accounting Office (GAO), an investigatory agency of the Congress. Noting that doubts about the safety of saccharin were raised in the early 1970 s, particularly after a study published in 1971 indicated that the sweetener may be a potential carcinogen, GAO suggested that "extended use of a food additive, such as saccharin, whose safety has not been established and for which a carcinogenic potential has been raised, could expose the public to unnecessary risk".

FDA did, however, take some action against saccharin in 1972. It limited the amount of the sweetener which could be added to food and drink, and ordered that the substance should be used only in special dietary products. The latter requirement hasn't been rigorously enforced, however, for use of the sweetener has mushroomed, diet sodas are heavily promoted for general use, and saccharin is now found in products like toothpaste and pancake syrup.

With such a large volume of sales to protect, the food industry is expected to appeal the ban, through the courts if necessary. Some nutritionists are warning of the health consequences of an increased consumption of sugar.

Colin Norman 